\title{
Associations between sociodemographic and behavioural variables, fanaticism and aggressiveness of soccer fans
}

\section{Asociaciones entre variables sociodemográficas y de comportamiento, fanatismo y agresividad de los fanáticos del fútbol}

\section{Associações entre variáveis sociodemográficas, comportamentais, fanatismo e agressividade de torcedores de futebol}

\author{
Geovani Garcia Zeferino, ORCID 0000-0002-8245-668x \\ Mônia Aparecida da Silva, ORCID 0000-0002-8840-7547 \\ Marco Antônio Silva Alvarenga, ORCID 0000-0002-1168-5733
}

\section{Universidade Federal de São João del-Rei, Brazil}

\begin{abstract}
Soccer fans' aggressiveness has serious consequences for individuals and society. However, its predictive factors have been poorly investigated. This study aimed to examine variables that predict soccer fans' aggressiveness. This survey, correlational and crosssectional research involved 210 participants, which were equivalent in crowd type (105 belonging to organized fan crowds and 105 not belonging to organized fan crowds), sex and age. The measurement instruments were: sociodemographic, occupational and behavioural questionnaires; the Fanaticism Scale for Football Fans; and the Buss and Perry Aggression Questionnaire. Results showed high aggressiveness in both groups and correlations between aggressiveness and fanaticism, sociodemographic and behavioural variables. Furthermore, the predictors of aggressiveness were fanaticism, age and time affiliated with the organized crowd. Therefore, it is concluded that sociodemographic and behavioural variables and fanaticism are important for understanding this phenomenon.
\end{abstract}

Keywords: aggressiveness; violence; fanaticism; soccer fans; organized fans.

Resumen: La agresividad de los fanáticos del fútbol tiene graves consecuencias para las personas y la sociedad. Sin embargo, sus factores predictivos han sido poco investigados. Por eso, este estudio buscó examinar variables que predicen la agresividad en fanáticos del fútbol. En los cuestionarios de esta investigación correlacional y transversal participaron 210 fanáticos, siendo equivalentes en tipo de multitud (105 pertenecientes a aficionados organizados y 105 no pertenecientes), sexo y edad. Los instrumentos de medición fueron: cuestionarios sociodemográficos, ocupacionales y de comportamiento, Escala de Fanatismo en Fanáticos del fútbol y Cuestionario de Agresión de Buss y Perry. Los resultados mostraron una alta agresividad en ambos grupos y correlaciones entre agresividad y fanatismo, variables sociodemográficas y de comportamiento. Además, los predictores de agresión fueron: fanatismo, edad y tiempo de afiliación. Se concluye que las variables sociodemográficas, de comportamiento y el fanatismo son importantes para comprender este fenómeno.

\section{(c) $\mathrm{EY}$}

This work is under a Creative Commons Attribution 4.0 International License 
Palabras clave: agresividad; violencia; fanatismo; fanáticos del fútbol; fanáticos organizados.

Resumo: A agressividade dos torcedores de futebol tem gerado graves consequências aos indivíduos e à sociedade. Entretanto, os fatores preditores têm sido pouco investigados. Este estudo objetivou examinar variáveis preditoras da agressividade desses torcedores. Esta pesquisa de levantamento, correlacional e corte transversal contou com 210 participantes, sendo equivalentes no tipo de torcida (105 pertencentes a torcidas organizadas e 105 não pertencentes), sexo e idade. Os instrumentos de medida foram: Questionários sociodemográfico, ocupacional e comportamental, Escala de Fanatismo em Torcedores de Futebol e Questionário de Agressão de Buss e Perry. Os resultados apontaram alta agressividade em ambos os grupos e correlações entre agressividade e fanatismo, variáveis sociodemográficas e comportamentais. Ademais, os preditores de agressividade foram fanatismo, idade e tempo filiado à torcida organizada. Portanto, conclui-se que as variáveis sociodemográficas e comportamentais e o fanatismo são importantes para o entendimento desse fenômeno.

Palavras-chave: agressividade; violência; fanatismo; torcedores de futebol; torcedores organizados.

Received: 06/04/2020

Accepted: 06/03/2021

How to cite:

Garcia Zeferino, G., Da Silva, M. A., Silva Alvarenga, M. A. (2021). Associations between sociodemographic and behavioural variables, fanaticism and aggressiveness of soccer fans. Ciencias Psicológicas, 15(2), e-2390. doi: https://doi.org/10.22235/cp.v15i2.2390

Correspondence: Geovani Garcia Zeferino, Universidade Federal de São João del-Rei, Brazil. E-mail: geogarciapsico@gmail.com

Soccer is the most followed sport in the world (Marchiori \& Vecchi, 2020; Turğut, Yaşar, Sunay, Özgen \& Beşler, 2018). The love of soccer makes fans gather in stadiums, pubs and places with other fans of the same team to watch matches and cheer together. However, there are situations in which this prestige becomes a rivalry capable of generating aggressiveness among fans (Murad, 2017).

Aggressiveness is defined as intentional conduct (Hilliard \& Johnson, 2018) which aims to cause some type of harm, whether physical or psychological, to other individual(s) or to onerself (Allen \& Anderson, 2017). In the soccer context, aggressiveness has been a serious social problem, occurring inside and outside stadiums through vandalism, fights and deaths (Murad, 2017; Van der Meij et al., 2015). Fan death rates have increased considerably (Gonçalves \& Dutra, 2018). In Brazil, for example, Murad (2017) states that in the period from 1999 to 2008, there were 42 deaths related to fan violence, and, from 2009 to 2016, that number increased to 134 . 
Studies have shown that fanaticism is a variable that is strongly related to fans' aggressiveness (Toder-Alon, Icekson \& Shuv-Ami, 2018; Winands, Grau \& Zick, 2017). Fanaticism consists of fans' exacerbated levels of identification with the team or with other fans (Murad, 2017), involving high levels of emotional, financial and time dedication to the team (Wachelke, Andrade, Tavares \& Neves, 2008). However, certain studies have found a weak (Hilliard \& Johnson, 2018) or non-significant relationship between aggressiveness and fanaticism (Dimmock \& Grove, 2005).

Another variable that is usually associated with fan aggressiveness is to belong to certain types of crowds. In some cases, fans choose to affiliate with organized crowds, that is, organizations with specified location, registration of members and rules, among other factors (Cordeiro \& Silva, 2017). Organized crowds play an encouraging role in the stadiums, due to their singing and cheering, generating a unique showing at soccer matches with their colours, costumes and choreography (Gonçalves \& Dutra, 2018; Lopes \& Hollanda, 2018). However, it is observed that some members of these crowds abandon the main objective of cheering and supporting the team and seek recognition for their actions, in order to impose a certain "superiority" in relation to opponents through fights (Gonçalves \& Dutra, 2018; Murad, 2017).

There are groups of fans who are internationally recognized for their aggressive behaviour, such as hooligans, ultras and barras bravas (Lopes \& Hollanda, 2018; Murad, 2017). However, studies are more interested in investigating the aggressiveness of specific groups of fans than comparing different groups to see if aggressiveness is a predominant characteristic of one crowd type in relation to another (Knapton, Espinosa, Meier, Bäck \& Bäck, 2018; Shoham, Dalakas \& Lahav, 2015).

Another point that is highlighted in the literature of the area is the influence of sociodemographic and behavioural variables on fan aggressiveness. Regarding participants' sex, studies generally show that men are more aggressive (Carriedo, Cecchini, \& González, 2020; Dimmock \& Grove, 2005; Turğut et al., 2018). However, there is generally a predominance of men in the study samples (Knapton et al., 2018; Shoham et al., 2015). Lower age is also generally related to a higher level of aggression (Murad, 2017; Toder-Alon et al., 2018), as well as alcohol and drug use (Brandão, Murad, Belmont \& Santos, 2020; Reis, Martins, Spaaij \& Lopes, 2018) and being single (Murad, 2017; Wann, Lane, Duncan \& Goodson, 1998). However, Silva, Freitas, Carvalho, Medeiros and Cardoso (2017) point out that there is still only a limited number of studies that characterize soccer fans in relation to these variables. Other authors have pointed out that those variables should also be considered in the construction of fan profiles for a better understanding of aggressiveness (Brandão et al., 2020; Reis et al., 2018).

Considering that soccer fans' aggressiveness is a multi-determined phenomenon (Brandão et al., 2020; Murad, 2017), questions are raised about how different variables can influence this type of conduct. Thus, the main objective of this study was to verify the relative importance of fanaticism, the type of crowd and sociodemographic and behavioural variables on soccer fans' aggressiveness. 


\section{Methods}

\section{Study design}

A quantitative, survey, correlational and cross-sectional study was carried out. We sought to describe sociodemographic, occupational habits and behaviours, as well as the levels of fanaticism and aggressiveness of soccer fans. Subsequently, the associations among these variables were verified. The sample was non-probabilistic and convenient (Neuman, 2014).

\section{Procedures}

Data were collected collectively at the organized crowd venues or in convenient places for participants, after an explanation of the procedure. No fans failed to respond or refused to participate in the study. Fans took an average of 20 minutes to complete the questionnaires. This study was approved by the Human Research Ethics Committee (CAAE: 13333619.0.0000.5151). All participants were informed about data confidentiality and anonymity and signed a free and informed consent form.

\section{Measures}

Sociodemographic and occupational questionnaire: This questionnaire assesses sociodemographic and occupational characteristics of sample participants through nine items. Variables such as sex, age, marital status and type of work, among others, were evaluated.

Questionnaire of habits and conduct of soccer fans: This questionnaire was constructed for this study from interviews with soccer fans and from the relevant extant literature to investigate behavioural variables related to aggressiveness. The questionnaire includes 22 items related to fans' routines.

Fanaticism Scale for Soccer Fans: This was developed and adapted to the Brazilian context by Wachelke et al. (2008) to assess different levels of fans' fanaticism with their team. It includes 11 items that address indicators of behaviours, situations and extreme beliefs linked to the act of cheering for a soccer team. It is a 7-point Likert-type scale, with responses varying between 1 (strongly disagree) and 7 (strongly agree). The scale presents satisfactory psychometric evidence regarding is internal structure (factor analysis and item-factor correlation), convergent validity with the Fan Identification Scale with the Team (Wachelke et al., 2008; $\mathrm{r}=.79 ; \mathrm{p}<.01)$ and internal consistency $(\alpha=.91)$.

Buss-Perry Aggression Questionnaire (BPAQ): This questionnaire was developed by Buss and Perry (1992) to assess aggression. It was adapted and validated to Brazil by Gouveia, Chaves, Peregrino, Branco and Gonçalves (2008). The BPAQ contains 26 items in four dimensions: (1) physical aggression; (2) verbal aggression; (3) anger, involves affective factors; and (4) hostility, includes cognitive factors. Responses are rated on a Likert-type scale ranging from 1 (strongly disagree) to 5 (strongly agree). The BPAQ shows a satisfactory internal structure validity evidence, through factor analysis, and reliability (internal consistency between $\alpha=.52$ and .81 and temporal stability from .76 to .80 between the first and second tests, global and by dimensions). 


\section{Participants}

Fans of both sexes aged 18 years or over, who were interested and willing to respond voluntarily to the procedures participated in this study. The sample comprised 210 soccer fans, 105 belonging to an organized crowd (TO) and 105 not belonging to an organized crowd ( $\mathrm{TnO}$ ). The groups ( $\mathrm{TO}$ and $\mathrm{TnO}$ ) were equivalent, that is, there were no significant differences between them in relation to sex, marital status, having children, having a job, watching soccer news and drinking at the stadium.

The average age of the TO group was 26.8 years $(\mathrm{SD}=7.9)$, the average age was 26.6 years for the $\mathrm{TnO}$ group $(\mathrm{SD}=7.8)$. The mean of years of schooling was 16.3 years $(\mathrm{SD}=$ 3.3) for $\mathrm{TO}$ and 16.2 years for $\mathrm{TnO}(\mathrm{SD}=2.8)$. There were no significant differences between the mean age and years of schooling between participants of the two groups. The target population is mostly single and has no children. Regarding occupation, in both groups, most people have a job of some kind, with the highest frequency having formal employment: 34 participants $(32.4 \%)$ in the TO group and $29(27.6 \%)$ in the TnO group. Of the 210 participants, only one reported not seeking out news about soccer. The average number of times per week that participants sought out news about soccer was 8.7 (SD =1.7) for TO and 5.8 (SD = 2.8) for TnO. Some fans' characteristics are described in Table 1, which also provides an analysis of the groups' equivalence for these variables. 
Table 1.

Sociodemographic and behavioural characteristics of soccer fans according to the participation (or lack therefore) in organized crowds

\begin{tabular}{|c|c|c|c|c|}
\hline & \multicolumn{2}{|c|}{ Type of crowd } & & \\
\hline & TO & $\mathrm{TnO}$ & \multicolumn{2}{|c|}{ Statistical tests } \\
\hline & \multicolumn{2}{|c|}{ Frequency (\%) } & $\chi^{2}$ & $p$ \\
\hline \multicolumn{5}{|l|}{ Sex } \\
\hline Male & $55(52.4)$ & $54(51.4)$ & \multirow{2}{*}{0.00} & \multirow{2}{*}{1.00} \\
\hline Female & $50(47.6)$ & $51(48.6)$ & & \\
\hline \multicolumn{5}{|l|}{ Marital status } \\
\hline Not married & $83(79.0)$ & $88(83.8)$ & \multirow{3}{*}{1.40} & \multirow{3}{*}{.50} \\
\hline Married / living with a partner & $19(18.1)$ & $16(15.2)$ & & \\
\hline Divorced / separated & $3(2.9)$ & $1(1.0)$ & & \\
\hline \multicolumn{5}{|l|}{ Has children? } \\
\hline Yes & $22(21.0)$ & $17(16.2)$ & \multirow{2}{*}{0.79} & \multirow{2}{*}{.38} \\
\hline No & $83(79.0)$ & $88(83.8)$ & & \\
\hline \multicolumn{5}{|l|}{ Works? } \\
\hline Yes & $67(63.8)$ & $63(60.0)$ & \multirow{2}{*}{0.32} & \multirow{2}{*}{.57} \\
\hline No & $38(36.2)$ & $42(40.0)$ & & \\
\hline \multicolumn{5}{|l|}{ Follows soccer news? } \\
\hline Yes & $105(100.0)$ & $104(99.0)$ & \multirow{2}{*}{1.01} & \multirow[b]{2}{*}{.32} \\
\hline No & $0(0)$ & $1(1.0)$ & & \\
\hline \multicolumn{5}{|c|}{ Alcohol use during a soccer match on TV? } \\
\hline Yes & $93(88.6)$ & $69(65.7)$ & \multirow{2}{*}{15.56} & \multirow{2}{*}{$.000 * *$} \\
\hline No & $12(11.4)$ & $36(34.3)$ & & \\
\hline \multicolumn{5}{|c|}{ Illicit drug use during a soccer match on TV? } \\
\hline Yes & $17(16.2)$ & $2(1.9)$ & \multirow{2}{*}{13.02} & \multirow{2}{*}{$.000 * *$} \\
\hline No & $88(83.8)$ & $103(98.1)$ & & \\
\hline \multicolumn{5}{|l|}{ Do you usually go to the stadium? } \\
\hline Yes & $105(100)$ & $71(67.6)$ & \multirow{2}{*}{40.57} & \multirow{2}{*}{$.000 * *$} \\
\hline No & $0(0)$ & $34(32.4)$ & & \\
\hline Alcohol use at the stadium? & & & & \\
\hline Yes & $76(72.4)$ & $47(66.2)$ & & \\
\hline No & $29(27.6)$ & $24(33.8)$ & 0.77 & .38 \\
\hline Illicit drug use at the stadium? & & & & \\
\hline Yes & $17(16.2)$ & $3(4.3)$ & & \\
\hline No & $88(83.8)$ & $67(95.7)$ & 5.88 & $.02 *$ \\
\hline Have you ever witnessed fights bety & & & & \\
\hline Yes & $95(90.5)$ & $73(69.5)$ & & \\
\hline No & $10(9.5)$ & $32(30.5)$ & 14.41 & $.000^{* *}$ \\
\hline Have you ever fought with other far & & & & \\
\hline Yes & $30(28.6)$ & $7(6.7)$ & 1725 & \\
\hline No & $75(71.4)$ & $98(93.3)$ & 17.35 & $.000^{* *}$ \\
\hline
\end{tabular}

Note: $\%=$ percentage $; \chi^{2}=$ Chi-Square; $\mathrm{p}=$ statistical significance; $* \mathrm{p}<.05, * * \mathrm{p}<.001$. 


\section{Data analysis}

Analysis was performed using the Statistical Package for Social Sciences (SPSS) software, version 20.0. Descriptive statistical analysis (mean, standard deviation and percentages) was used to characterize sociodemographic and occupational variables and fan habits and behaviours, as well as the scores in the measurement instruments. A chi-square test was used to verify groups' equivalence in relation to these variables.

The Shapiro-Wilk test was used to check the normality of the dependent variable (total score of aggressiveness) in order to choose the kind of inferential statistical techniques. It was found that the data do not follow the normal distribution $(\mathrm{p}=.000)$. Thus, nonparametric statistics were used.

To test for differences in the means for fans' characteristics related to the level of aggressiveness, the Mann-Whitney U test was used to compare two means, and the KruskalWallis test for marital status was used to compare three means. To verify the existence of mean differences in fanaticism between the TO and TnO groups, the Mann-Whitney test was also used. In pairs with significant differences, the effect size between the groups' difference was calculated using an online calculator, available on the University of Colorado website (https://www.uccs.edu/lbecker/). The effect size is considered small (from 0.1 to 0.3), moderate (from 0.3 to 0.5 ) and large (greater than 0.5) (Rice \& Harris, 2005). Spearman's correlation coefficient was used to analyse the association between continuous variables and fans' aggressiveness.

Finally, to verify the relative influence of the characteristics of fans and fanaticism on aggressiveness, binary logistic regression analysis was performed. This analysis was chosen because of the non-normality of the dependent variable. To separate the groups in a dichotomous way, the median of the total score of aggressiveness was used as the cut-off point. The variables that were significantly associated with aggressiveness in the bivariate analyses were inserted into the model by the enter method. The assumptions necessary to perform the binary logistic regression were checked, namely: absence of collinearity between the predictors; absence of outliers; and number of participants per predictor (minimum of 10 per independent variable; Field, 2009). All assumptions were met.

\section{Results}

Table 2 shows the aggressiveness means, global and by dimensions, and fanaticism means, for TO and TnO, as well as a comparison between the groups in these variables. Based on the validity study for the BPAQ (Gouveia et al., 2008) and on the data graphic inspection for both groups, it was found that they had high means in aggressiveness (data asymmetry to right of the normal curve).

The aggressiveness comparison between the groups showed that TO had higher means, both in the global score and in the dimensions. Differences between the groups were statistically significant for all variables. It was found that all effect sizes of the difference between the group means were large (Rice \& Harris, 2005). Regarding fanaticism, the TO group mean was also significantly higher than that of the $\mathrm{TnO}$ group. The effect size of the difference was large. 
Table 2.

Description and comparison of mean scores of aggressiveness, global and by dimension, and fanaticism of the participants according to the type of crowd

\begin{tabular}{cccccccc}
\hline & \multicolumn{3}{c}{ Type of crowd } & \multicolumn{3}{c}{ Statistical tests and effect } \\
& TO & TnO & TO & TnO & \multicolumn{3}{c}{ size } \\
\hline \multirow{2}{c}{ Mean $(S D)$} & \multicolumn{2}{c}{ Ranks mean } & $U$ & $p$ & $r$ \\
BPAQ total score & $95.4(11.1)$ & $66.6(16.6)$ & 149.1 & 61.9 & 940.5 & $.000^{* *}$ & 0.7 \\
Physical Aggression & $25.9(4.3)$ & $15.5(6.1)$ & 147.3 & 63.7 & 1123.0 & $.000^{* *}$ & 0.7 \\
Verbal Aggression & $16.4(2.5)$ & $11.6(3.7)$ & 143.2 & 67.8 & 1553.0 & $.000^{* *}$ & 0.6 \\
Anger & $22.1(5.0)$ & $15.0(5.6)$ & 142.4 & 68.6 & 1650.5 & $.000^{* *}$ & 0.6 \\
Hostility & $31.0(4.7)$ & $24.5(5.6)$ & 138.1 & 72.9 & 2089.0 & $.000^{* *}$ & 0.5 \\
Fanaticism & $65.0(5.4)$ & $39.3(14.9)$ & 152.8 & 58.2 & 547.0 & $.000^{* *}$ & 0.8 \\
\hline
\end{tabular}

Note: $\mathrm{SD}=$ standard deviation; $\mathrm{U}=$ Mann-Whitney statistic; $\mathrm{r}=$ effect size between 0.1 and $<0.3$, small, between 0.3 and $<0.5$, moderate and $>0.5$, large; BPAQ total score $=$ Total aggressiveness score; $* *$ p $<.001$.

Analysis of the associations between aggressiveness and participants' characteristics is presented in Tables 3 and 4. Correlational analysis was carried out to verify associations between aggressiveness and some continuous variables. The results indicated that the strongest association of aggressiveness was with fanaticism $(\mathrm{p}=.000)$, indicating that the higher the level of aggressiveness, the greater the fanaticism. The number of times per week that the fan seeks out news about the team - which is associated with the degree of fanaticism - also showed a positive and significant correlation with aggressiveness $(p=.000)$. The age of the fans was negatively correlated with aggressiveness $(\mathrm{p}=.014)$, indicating that the older the fan's age, the lower the aggressiveness. The number of years of education and the time of affiliation with the organized crowd had no significant association with aggressiveness.

Table 3.

Correlational analysis between participants' characteristics and total aggressiveness score

\begin{tabular}{llllll}
\hline & Fanaticism & Age & $\begin{array}{l}\text { Years of } \\
\text { study }\end{array}$ & $\begin{array}{l}\text { Number of times per } \\
\text { week searching for } \\
\text { team news }\end{array}$ & TO membership time \\
\hline BPAQ Global & $0.80^{* *}$ & $-0.17^{*}$ & -0.12 & $0.43^{* *}$ & -0.07 \\
\hline
\end{tabular}

Note: BPAQ Global = aggressiveness total score $* *$ ${ }^{*}<.001 ; * \mathrm{p}<.05$.

Participants who reported consuming alcohol and/or illicit drugs when watching soccer matches on TV and illicit drugs at the stadium, those who typically go to the stadium and those who witnessed or were involved in fights with other fans had significantly higher scores for aggression compared to participants who did not present these characteristics. The 
effect size of the difference between the means was moderate for all comparisons. The sociodemographic variables of sex, marital status, having children and having formal employment were not significantly associated with the aggressiveness of the fans.

Table 4.

Comparative analysis of means of aggression in relation to sociodemographic and behavioural characteristics of the participants

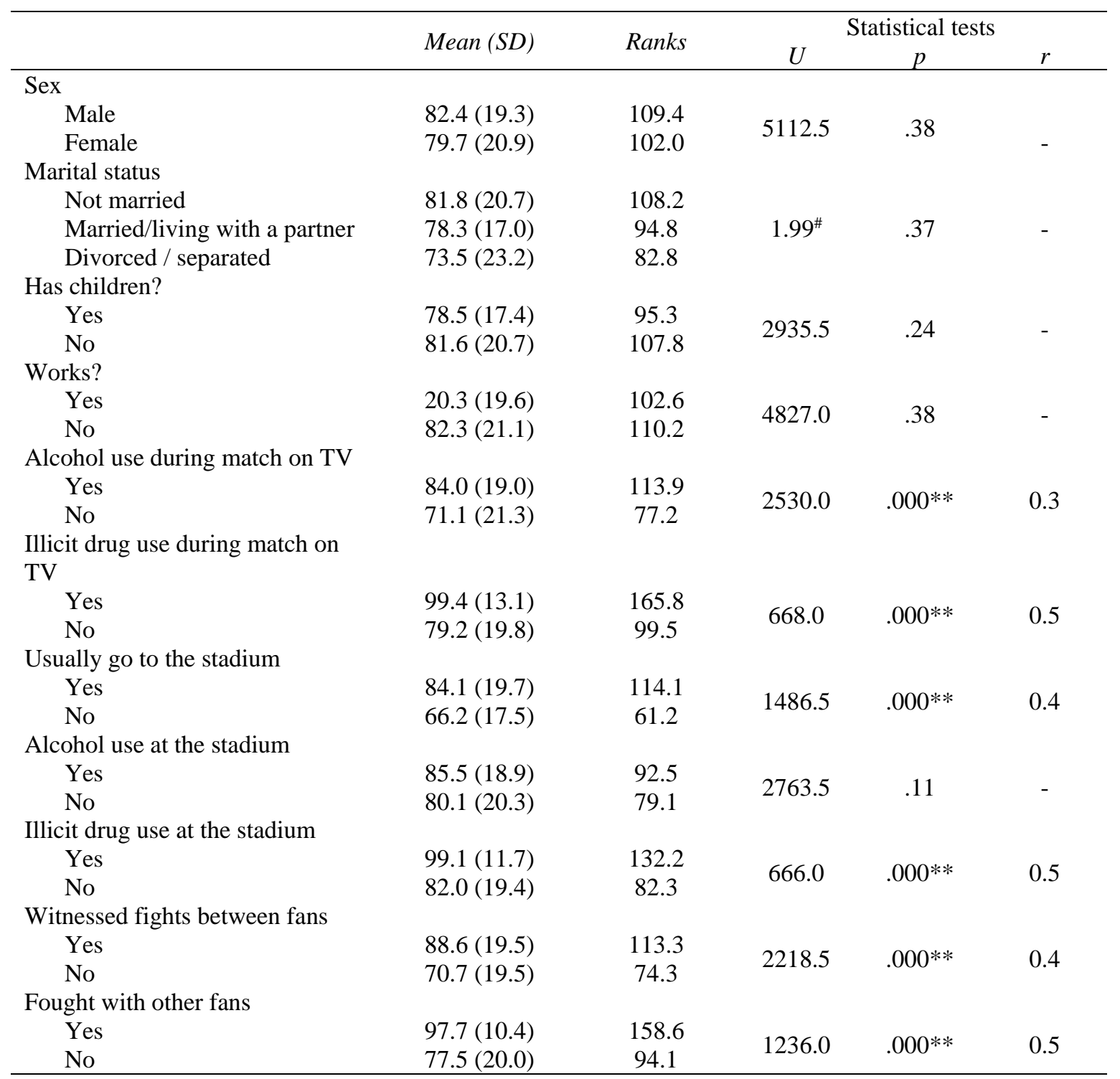

Note: $\mathrm{SD}=$ standard deviation; $\mathrm{U}=$ Mann Whitney statistic; $\mathrm{p}=$ statistical significance; $\mathrm{r}=$ effect size, between 0.1 and $<0.3$, small, between 0.3 and $<0.5$, moderate and $>0.5$, large; \#Kruskal Wallis test; $* * \mathrm{p}<.001$. 
Table 5 presents the predictors that remained significant in the binary logistic regression. Variables that were significantly associated with aggressiveness in the bivariate analyses were included in the model: level of fanaticism; age; type of crowd; alcohol and drug use when watching soccer matches on TV; drug use in the stadium; having witnessed fights between fans; and being involved in fights with other fans due to soccer. The model containing the variables of fanaticism, age and TO time of membership was significant $[\chi 2$ $(1)=172.03 ; p=.000, \mathrm{R} 2$ Negelkerke $=0.849]$. Results indicated that the increase of one point in the fanaticism score increased the risk of aggressiveness 1.54 times. Likewise, being younger increased the risk of aggressiveness by 0.89 times and being affiliated with an organized crowd increased the risk of aggressiveness by 0.17 times.

Table 5.

Variables explaining fans' aggressiveness that remained significant in the multivariate logistic regression model

\begin{tabular}{lcccccc}
\hline \multirow{2}{*}{ Variables } & \multirow{2}{*}{$\mathrm{B}$} & \multirow{2}{*}{ S.E. } & \multirow{2}{*}{ EXP(B) } & \multicolumn{2}{c}{ Bivariate analysis (IC 95\%) } & \multirow{2}{*}{ Sig. } \\
\cline { 1 - 3 } & & & & Lower & Upper & \\
\hline Fanaticism & 0.432 & 0.102 & 1.540 & 1.260 & 1.882 & 0.000 \\
Age & -0.116 & 0.040 & 0.891 & 0.823 & 0.964 & 0.004 \\
Affiliated to TO & -1.791 & 0.764 & 0.167 & 0.037 & 0.745 & 0.019 \\
\hline
\end{tabular}

Note $:$ Cox \& Snell = 0.634; Nagelkerke = 0.849; B = Beta; S.E. $=$ standard error; EXP $(B)=$ odds ratio; IC $95 \%$ = confidence interval; Sig. = statistical significance ( $\mathrm{p}$ value).

\section{Discussion}

This study's main objective was to verify the relative importance of fanaticism, the type of crowd and the fans' sociodemographic and behavioural variables in soccer fan aggressiveness. It was observed through data asymmetry and visual inspection of scatter plots that in both groups (TO and TnO), aggressiveness means were high, corroborating with previous studies (Murad, 2017; Silva et al., 2017), which have stated that aggressiveness is not exclusive to organized crowd groups.

Regarding fanaticism, the means were also higher in the TO group, in accordance with Van der Meij et al. (2015), who demonstrated greater fanaticism in groups of fans. This result is in line with everyday situations, where increased fan involvement is related to behaviours such as going to matches more frequently and buying more sporting goods and items related to the club (Britto \& Mattoso, 2018), as well as being more excited to cheer and talk about the team (Gonçalves \& Dutra, 2018; Wachelke et al., 2008) and travel to other cities due to the team's matches (Hollanda \& Medeiros, 2016; Winands et al., 2017).

Furthermore, Souza (2020) highlighted that some fans receive financial support from team managers to purchase tickets and to pay for trips to go to matches. It is hypothesized that this financial support contributes to fans going to the stadiums and, consequently, the incentive for their soccer team to win is greater. However, this closer monitoring of athletes' daily life and team performance by the fans has favoured the increase in fans' identification and loyalty to the team. It can contribute to higher levels of fanaticism (Dwyer, LeCrom \& 
Greenhalgh, 2016). In addition, more active participation of fans can cause aggressive charges for soccer players and team managers. Therefore, the directors of some teams reduced and/or cut these financial collaborations, leading many organized crowds to seek financial autonomy (Souza, 2020). We suggest that future studies investigate whether these financial aspects affect fans' behaviour.

The present study identified positive and high correlations between aggressiveness and fanaticism, demonstrating that the higher the level of aggressiveness, the greater the level of fanaticism. In addition, the number of times per week that a fan sought out news about his team, a direct indicator of fanaticism, was positively correlated with aggressiveness. These results are consistent, considering that they are similar to many previous studies (Knapton et al., 2018; Van der Meij et al., 2015). They are, however, different from those found by Hilliard and Johnson (2018) and Dimmock and Grove (2005), who did not find a consistent association between fanaticism and aggressiveness. This difference in results could be due to the sample characteristics of these two studies. In these studies, the participants did not belong to organized crowds: they were university students (Hilliard \& Johnson, 2018) and people from the community (Dimmock \& Grove, 2005). Additionally, these studies were done with mixed samples of soccer fans and fans of other sports, in countries where soccer is not as traditional, which is generally associated with less fanaticism. Considering the literature, there seems to be a consistent relationship between fanaticism and aggressiveness. This finding suggests that the level of fans' fanaticism helps us to understand the serious episodes of aggressiveness and violence that have occurred in the soccer context.

Regarding sociodemographic characteristics, in the present study, sex did not correlate with aggressiveness, contrary to previous studies (Carriedo et al., 2020; Murad, 2017). Another disagreement with previous studies (Murad, 2017; Wann et al., 1998) is the associations of aggressiveness with marital status and having children, as in the present study, such an association did not occur. Wann et al. (1998), for example, found that practically half of respondents who were married and had children showed less tendency and interest in aggressiveness in relation to singles and individuals who did not have children. In the present study, there was also no relationship between the variable of having a job and aggressiveness. This result is convergent with previous studies and refutes public opinion by labelling fans as "vagabonds, idlers, etc." (Hollanda \& Medeiros, 2016).

In addition, habits and behaviours, that is, behavioural variables, were also investigated. Alcohol and drug use showed significant correlations with aggressiveness, corroborating studies on this issue in the soccer context (Brandão et al., 2020; Reis et al. 2018). In addition, as in the present sample, in the study by Brandão and colleagues (2020), alcohol and drug use were more significant in organized crowds and, in some cases, on match days. These findings confirm that alcohol and other drug use is a risk for aggressiveness and, consequently, for violence. Other variables, such as going to the stadium, witnessing or getting involved in fights with other fans, also correlated with aggressiveness. This fact corroborates results of other studies on this theme, which have reported a certain "stimulus to fight" when fans get involved with confusion at sporting events (Hollanda \& Medeiros, 2016; Van der Meij et al., 2015). 
The multivariate model, which assessed the simultaneous relative influence of all variables associated with fan aggressiveness in previous analyses, indicated that fanaticism was the variable that most explained the increase in aggressiveness, followed by younger age and type of crowd (in this case, belonging to the organized crowd). Higher levels of fanaticism were predictors of the greater aggressiveness of soccer fans. This result is in line with previous research (Toder-Alon et al., 2018; Van der Meij et al., 2015; Winands et al., 2017). Younger age explained part of the aggressiveness increase. An association between these variables was found previously (Toder-Alon et al., 2018). This fact can perhaps be explained by the fan's life span, which involves changes, maturation and emotional factors (Murad, 2017). Another predictor of aggressiveness identified in the present study refers to affiliation time to the organized crowd. The shorter affiliation time explained part of the increase in aggressiveness. This fact can be explained due to the beneficial effect of the passage of time, which allows the individual to understand the real purpose of the organized crowd: to support the team (Murad, 2017).

This study presents an advance by the equalization of the groups in relation to the type of soccer crowd, sex and age of fans. Thus, its potential to mitigate the effect of some spurious variables is emphasized, and the results are less impacted by sample biases, as recommended by Neuman (2014). Related to sex, for example, in previous studies, there was a predominance of men, demonstrating that women are still, globally, underrepresented in most soccer stands (Knapton et al., 2018; Shoham et al., 2015). Another study potential was to compare crowd types, favouring the identification of individual and group profiles more willing to act aggressively and, therefore, allowing us to develop preventive strategies for those who showed greater tendencies towards aggressiveness.

This study has certain limitations. The main limitation refers to sample biases. The high scores of aggressiveness may be explained by the fact that most of the respondents support a team that, at the time of data collection, faced a difficult time in the championships, with risk of demotion and internal crises. This situation leads to a great deal of provocation by opposing fans. Therefore, such participants may have responded to the instrument based on their feelings (stress and frustration), which may have caused them to score more aggressively (Silva et al., 2017; Van der Meij et al., 2015).

The measurement of aggressiveness may also have influenced the results. The BPAQ evaluates aggressiveness as a trend, based on behaviours presented by the person in different situations of his or her life. It can be used for the general population, including soccer fans. However, it is understood that some items would have a different score if they reflected situations experienced in the soccer context, such as item 3, "Some friends say that I am hot headed" or item 22, "Once in a while, I cannot control the desire to hit another person". Fanatical fans tend to score higher for most items of aggressiveness when they scored them considering the soccer context in particular. Thus, if fans responded to some items prioritizing soccer, these items might not be sensitive to detecting the trend of the individual's overall aggressive behaviour. The high aggressiveness scores in the present study also raise a possible question about the way that BPAQ measures aggressiveness, considering hypothetical behaviours or based on the respondent's general experiences, such as item 1, "If someone hits me, I hit back" and item 7, "I suspect strangers who are too friendly". If the item had measured the occurrence and not the intention to perform the behaviour, the aggressiveness scores could have been slightly lower. However, the potential of the 
dimensions of the BPAQ stands out in reflecting broad aspects of aggression - and not only physical aggression or attacks against others, as had already been demonstrated in previous studies with fans (Knapton et al., 2018; Shoham et al., 2015; Turğut et al., 2018).

In view of the limitations found, it is evident that some points may provide guidance for future studies. Firstly, it is believed that it is important to compare organized crowds from inland cities and from capitals, since they possibly have different characteristics. In addition, future studies investigating soccer fans' aggressiveness with specific instruments, addressing different dimensions of aggressiveness -involving the direct impact and intention to engage in aggressive behaviours- can contribute to understanding this phenomenon in the soccer context. According to Wachelke et al. (2008), by using specific instruments for the population of soccer fans, it is possible to capture with more precision the specific details, behaviours and reality of fans.

\section{Conclusions}

The present study showed high levels of aggressiveness in soccer fans and their associated factors. These findings give rise to concerns for public authorities and different people involved with soccer and sports, calling attention to the urgency need to discuss strategies to reduce aggressiveness and its consequences.

Strategies successful employed in Europe for social control of hooligans can influence practices in Brazil. In the short term, useful strategies involve greater control of ticket sales and access to stadiums, as well as identification of aggressive fans through cameras monitoring, with resulting punishment for offenders. In the medium term, investigations and research on the responsibility of people and organizations involved in soccer can identify possible causes of violence and, consequently, contribute to combatting and preventing it. In the long term, educational strategies can be developed, such as raising awareness and creating campaigns focused on the non-violence culture, both in stadiums and in the media.

It is expected that future studies continue exploring predictors of behaviour that is harmful to individual and collective health in the soccer context. Greater government involvement in legislative strategies is also expected since aggressiveness in soccer is a public health problem in several countries.

\section{Funding}

This study was financed in part through scholarship provided to the first author by Coordenação de Aperfeiçoamento de Pessoal de Nível Superior - Brasil (Capes) - Finance Code 001. 


\section{References}

Allen, J. J., \& Anderson, C. A. (2017). General aggression model. The international encyclopedia of media effects, 1-15. doi: https://doi.org/10.1002/9781118783764.wbieme0078

Brandão, T., Murad, M., Belmont, R., \& Santos, R. F. (2020). Álcool e violência: Torcidas organizadas de futebol no Brasil. Movimento (ESEFID/UFRGS), 26, 1-14. doi: https://doi.org/10.22456/1982-8918.90431

Britto, F. R., \& Mattoso, C. Q. (2018). Consumo sagrado ou sagrado consumo? As implicações dessa sacralização na hierarquia de valores. Pensamento \& Realidade, 33(2), 48-64.

Buss, A. H., \& Perry, M. (1992). The aggression questionnaire. Journal of Personality and Social Psychology, 63(3), 452-459. doi: http://doi.org/10.1037/0022-3514.63.3.452

Carriedo, A., Cecchini, J. A., \& González, C. (2020). Soccer spectators' moral functioning and aggressive tendencies in life and when watching soccer matches. Ethics \& Behavior, 1-15. doi: https://doi.org/10.1080/10508422.2020.1715801

Cordeiro, L. B., \& Silva, S. R. (2017). Sobre Torcedores Organizados Brasileiros em Contextos Migrantes: Um Estudo Exploratório. Revista do Programa de Pósgraduação Interdisciplinar em Estudos do Lazer, 20(2), 99-138.

Dimmock, J. A., \& Grove, J. R. (2005). Relationship of fan identification to determinants of aggression. Journal of Applied Sport Psychology, 17(1), 37-47. doi: https://doi.org/10.1080/10413200590907559

Dwyer, B., LeCrom, C., \& Greenhalgh, G. P. (2016). Exploring and measuring spectator sport fanaticism. Communication and Sport, 6(1), 58-85. doi: https://doi.org/10.1177/2167479516679411

Field, A. (2009). Descobrindo a estatística usando o SPSS-2 (2 ${ }^{\circ}$ ed.). Porto Alegre: ArtMed Editora.

Gonçalves, A. D. A. A., \& Dutra, R. C. (2018). A preservação da ordem pública nos estádios de futebol por meio do cadastramento biométrico das torcidas organizadas no estado de Santa Catarina. Revista Ordem Pública, 10(1), 95-114.

Gouveia, V. V., Chaves, C. M. C. M., Peregrino, R. R., Branco, A. O. C., \& Gonçalves, M. P. (2008). Medindo a agressão: o Questionário de Buss-Perry. Arquivos Brasileiros de Psicologia, 60(3), 92-103.

Hilliard, R. C., \& Johnson, C. G. (2018). Sport Fan Attitudes and Willingness to Commit Aggressive Acts. Journal of Sport Behavior, 41(3), 305-329.

Hollanda, B. B. B., \& Medeiros, J. (2016). Violência, juventude e idolatria clubística: Uma pesquisa quantitativa com torcidas organizadas de futebol no Rio de Janeiro e em São Paulo. Revista Hydra: Revista Discente de História da UNIFESP, 1(2), 97-125. doi: https://doi.org/10.34024/hydra.2016.v1.9135

Knapton, H., Espinosa, L., Meier, H. E., Bäck, E. A., \& Bäck, H. (2018). Belonging for violence: Personality, football fandom, and spectator aggression. Nordic Psychology, 70(4), 278-289. doi: https://doi.org/10.1080/19012276.2018.1430611

Lopes, F. T. P., \& Hollanda, B. B. B. D. (2018). "Ódio eterno ao futebol moderno": poder, dominação e resistência nas arquibancadas dos estádios da cidade de São Paulo. Tempo, 24(2), 206-232. doi: https://doi.org/10.1590/tem-1980-542x2018v240202 
Marchiori, M., \& Vecchi, M. (2020). Secrets of soccer: Neural network flows and game performance. Computers \& Electrical Engineering, 81, 106505. doi: https://doi.org/10.1016/j.compeleceng.2019.106505

Murad, M. (2017). A violência no futebol: novas pesquisas, novas ideias novas propostas (2 ${ }^{\mathrm{a}}$ ed.). São Paulo: Benvirá.

Neuman, W. L. (2014). Social research methods: Qualitative and quantitative approaches (7th ed.). Pearson education.

Reis, H. H. B., Martins, M. Z., Spaaij, R., \& Lopes, F. T. P. (2018). Drinking dangerously? Revista Brasileira de Educação Física e Esporte, 32(2), 277-288. doi: https://doi.org/10.11606/1807-5509201800020277

Rice, M. E., \& Harris, G. T. (2005). Comparing effect sizes in follow-up studies: ROC Area, Cohen's d, and r. Law and human behavior, 29(5), 615-620. doi: https://doi.org/10.1007/s10979-005-6832-7

Shoham, A., Dalakas, V., \& Lahav, L. (2015). Consumer misbehavior: Aggressive behavior by sports fans. Services Marketing Quarterly, 36(1), 22-36. doi: https://doi.org/10.1080/15332969.2015.976506

Silva, W. R., Freitas, K. T. D., Carvalho, H. P., Medeiros, T., \& Cardoso, F. L. (2017). Torcedores de clubes de Futebol da cidade de Florianópolis: perfil sociodemográfico e comportamental. Revista Brasileira de Futsal e Futebol, 9(33), 197-205.

Souza, E. A. P. (2020). As gerações de grupos organizados de torcedores no Brasil. Revista Eletrônica de Ciências Sociais, (31), 192-218. doi: https://doi.org/10.34019/19812140.2020.30164

Toder-Alon, A., Icekson, T., \& Shuv-Ami, A. (2018). Team identification and sports fandom as predictors of fan aggression: The moderating role of ageing. Sport Management Review, 22(2), 194-208. doi: https://doi.org/10.1016/j.smr.2018.02.002

Turğut, M., Yaşar, O. M., Sunay, H., Özgen, C., \& Beşler, H. K. (2018). Evaluating aggression levels of sport spectators. European Journal of Physical Education and Sport Science, 4, 1-12. doi: https://doi.org/10.5281/zenodo.1196665

Van der Meij, L., Klauke, F., Moore, H. L., Ludwig, Y. S., Almela, M., \& Van Lange, P. A. M. (2015). Football Fan aggression: the importance of low basal cortisol and a fair referee. PloS One, 10(4). doi: https://doi.org/10.1371/journal.pone.0120103

Wachelke, J. F., Andrade, A. L. D., Tavares, L., \& Neves, J. R. (2008). Mensuração da identificação com times de futebol: evidências de validade fatorial e consistência interna de duas escalas. Arquivos Brasileiros de Psicologia, 60(1), 96-111.

Wann, D. L., Lane, T. M., Duncan, L. E., \& Goodson, S. L. (1998). Family status, preference for sport aggressiveness, and sport fan motivation. Perceptual and motor skills, 86(3 suppl.), 1419-1422. doi: https://doi.org/10.2466/pms.1998.86.3c.1419

Winands, M., Grau, A., \& Zick, A. (2017). Sources of identity and community among highly identified football fans in Germany. An empirical categorisation of differentiation processes. Soccer \& Society, 20(2), 216-231. doi: https://doi.org/10.1080/14660970.2017.1302934 
Authors' participation: a) Conception and design of the work; b) Data acquisition; c) Analysis and interpretation of data; d) Writing of the manuscript; e) Critical review of the manuscript.

G. G. Z. has contributed in a, b, c, d, e; M. A. S. in a, c, d, e; M. A. S. A. in a, c, d, e.

Scientific editor in charge: Dra. Cecilia Cracco. 